\title{
Communication strategies of English native speaker teacher in the teaching and learning process in a kindergarten
}

\author{
Ni Made Mestriani*, I Ketut Seken, and I Nyoman Adi Jaya Putra \\ Universitas Pendidikan Ganesha, Singaraja, Bali, Indonesia
}

\begin{abstract}
In Dyatmika Kindergarten, the students came from different cultural backgrounds and nations. They were taught by English native speaker teacher in English sessions. The students sometimes might understand the intention of the teacher; however, sometimes they might not understand at all. Therefore, the teacher should know how they communicate with the students to avoid misunderstanding. This study aimed at identifying, describing and explaining communication strategies used by English native speaker teacher at Dyatmika Kindergarten during English sessions of the teaching and learning process. This study used descriptive qualitative design, and the data collected through observation and interview. The data were analyzed using taxonomy of communication strategies by Dornyei and Scott (1995). The result indicated there were thirteen communication strategies used by the English native speaker teacher in teaching and learning process. The use of communication strategies by English native speaker teacher was expected to inspire other teachers inside and outside Dyatmika Kindergarten when they communicate with students and make the students understand the message conveyed by the teachers.
\end{abstract}

Keywords: communication strategies, English native speaker teacher, Dyatmika Kindergarten

\section{Introduction}

Teaching and learning are two things that cannot be defined apart. According to Brown [1], teaching is a guiding and facilitating learning, enabling learner to learn and setting condition for learning. [1] learning means acquiring knowledge of a subject or a skill by study, experience or instruction. [2] supported that learning serves a basis for future progress in society. The purpose of teaching and learning could be accomplished when the strategy of teachers in communicating in the class could be understandable by the students.

Dyatmika Kindergarten is a bilingual school which is located in Denpasar, Bali, Indonesia. The school have students who come from different cultural background and nations. The English native speaker (ENS) teacher teaches in English sessions. The students have to communicate using English to be able to interact with other students and the teacher. When the students have less English vocabulary, they would have less

* Corresponding author: made.mestri@gmail.com 
comprehension of what the teacher expressed during the teaching and learning process. Furthermore, they would be hard to comprehend the message. Thus, the teacher should know how to communicate the message as clear as possible to the students.

English native speaker teacher in Dyatmika Kindergarten owns communicative competence. The teacher tries to reach communication goals in the class that could promote students' English learning. Canale and Swan in [1] mentioned one of communicative competence is strategic competence which means verbal and nonverbal communication strategies that might be called into action to compensate for breakdowns in communications due to performance variables or insufficient competence. [3] added communication strategy is an effort done by individuals to solve the problem when they tried to communicate and they have limited available linguistic resources. Relating to this study, communication strategies were used to keep the communication going well in teaching learning process and to make the students involve in classroom interaction.

[4] conducted research on communication strategies used by English teachers at junior high school in Sukawati, Gianyar, Bali. The result showed the teachers used fourteen communication strategies. They were used to enhance students' speaking abilities during the process of learning. Moreover, [5] conducted a study on communication strategies used by Mathematics and Science teachers to communicate in English in morning sharing at junior high school. The result showed the use of communication strategies by the teachers aimed at keeping the conversation in the class going smoothly.

Related to this study, a preliminary observation was done to see how the English native speaker teacher communicated with bilingual kindergarten students and made them understand in defining teacher's intentions. Sometimes the students could understand easily; however, sometimes they could not comprehend at all. This situation made the teacher should have certain communication strategies to assist them solve the problem in communicating with the students especially during English sessions.

Therefore, this study was conducted to identify, describe and explain communication strategies used by English native speaker teacher at Dyatmika Kindergarten. A classification of communication strategies by Dornyei and Scott in [6] was used as a basis to analyze types of communication strategies used by the teacher. They classified the strategies into three namely direct strategies (message abandonment, message reduction, message replacement, circumlocution, approximation, use all-purpose word, word-coinage, restructuring, literal translation, foreignizing, code switching, use similar sounding words, mumbling, omission, retrieval, self-repair, other-repair, self-rephrasing, over-explicitness, mime), indirect strategies (use of fillers, self-repetition, other-repetition, feigning understanding, verbal strategy makers), and interactional strategies (direct appeal for help, indirect appeal for help, asking for repetition, asking for clarification, asking for confirmation guessing, expressing non-understanding, interpretative summary, comprehension check, own accuracy check, responses).

The communication strategies used in Dyatmika Kindergarten showed how the teacher attempted to communicate clearly with kindergarten students and make them understand the intentions. Consequently, this could make them involve in the lesson and they have meaningful learning. Further, this study result could give inspiration for other teachers in communicating with kindergarten students. It could let the people who do not teach at Dyatmika Kindergarten knowing the way how communication strategies happen in the school and how the strategies could work well for students' understanding of the message. Thus, the communication strategies used by English native speaker teacher at Dyatmika Kindergarten could be a model in teaching kindergarten students. 


\section{Methods}

This qualitative study focused on the use of communication strategies by English native speaker teacher in English sessions at bilingual school. In addition, the main source of the data was English native speaker teacher at Dyatmika Kindergarten B in academic year 2016/2017 to know the communication strategies used in teaching bilingual students.

The data of this study were collected through observation and interview. The observation was done by videoing the teaching and learning activities spesifically when the teacher sat together with the students and they learnt classically on the carpet. Moreover, interview was another method to collect the data in this qualitative study to gain more information related to the use of communication strategies.

Once the teaching and learning activities in English sessions were recorded and transcribed, communication strategies taxonomy of Dornyei and Scott in [6] was used as basis to analyze types of communication strategies used by the teacher. In analysing the data of observation and interview, this study adapted a number of data analysis by Miles and Huberman [7] namely data reduction, data display and conclusion drawing/verification.

\section{Results}

As shown in Table 1, the English native speaker teacher used thirteen communication strategies proposed by Dornyei and Scott in [6]. There were four direct strategies, three indirect strategies and six interactional strategies.

Table 1. Types of Communication Strategies used by English Native Speaker Teacher

\begin{tabular}{|c|c|c|c|}
\hline No. & \begin{tabular}{|c|} 
Types of \\
Communication \\
Strategies \\
\end{tabular} & $\begin{array}{c}\text { Sub-type of } \\
\text { Communication } \\
\text { Strategies } \\
\end{array}$ & Motives \\
\hline \multirow{4}{*}{1} & \multirow{4}{*}{$\begin{array}{l}\text { Direct } \\
\text { Strategies }\end{array}$} & Code-switching & To make the students understand the intentions \\
\hline & & Self-repair & $\begin{array}{l}\text { To tell the students appropriate words to be used in } \\
\text { saying something }\end{array}$ \\
\hline & & Other-repair & $\begin{array}{l}\text { To make the students know the appropriate words to be } \\
\text { used in telling their intention }\end{array}$ \\
\hline & & Self-rephrasing & To simplify the message delivered to the students \\
\hline \multirow{3}{*}{2} & \multirow{3}{*}{$\begin{array}{l}\text { Indirect } \\
\text { Strategies }\end{array}$} & Use of fillers & $\begin{array}{l}\text { To be more friendly to the students and to gain time to } \\
\text { think what to do next in the discussion }\end{array}$ \\
\hline & & Self-repetition & $\begin{array}{l}\text { To tell information to the students and to order students } \\
\text { to do something }\end{array}$ \\
\hline & & Other-repetition & $\begin{array}{l}\text { To make sure all students listen and know the } \\
\text { appropriate answer in the discussion }\end{array}$ \\
\hline \multirow{6}{*}{3.} & \multirow{6}{*}{$\begin{array}{l}\text { Interactional } \\
\text { Strategies }\end{array}$} & $\begin{array}{l}\text { Asking for } \\
\text { repetition }\end{array}$ & To have clear information from the students \\
\hline & & $\begin{array}{l}\text { Asking for } \\
\text { clarification }\end{array}$ & $\begin{array}{l}\text { To gain more information and it would make other } \\
\text { students learn from their friends }\end{array}$ \\
\hline & & $\begin{array}{l}\text { Asking for } \\
\text { confirmation }\end{array}$ & $\begin{array}{l}\text { To avoid misunderstanding between the students and } \\
\text { teacher }\end{array}$ \\
\hline & & Guessing & $\begin{array}{l}\text { To support the students by giving the words that they } \\
\text { tried to think of. }\end{array}$ \\
\hline & & $\begin{array}{l}\text { Comprehension } \\
\text { check }\end{array}$ & $\begin{array}{l}\text { To ensure students' understanding and involve the } \\
\text { students in the lesson }\end{array}$ \\
\hline & & Responses & $\begin{array}{l}\text { To respond what the students shared so they know the } \\
\text { answers exactly }\end{array}$ \\
\hline
\end{tabular}


In direct strategies, first, the English native speaker teacher used code switching. She switched English to Indonesian language to tell the context of words to the students. She used this strategy because some local students did not understand the words in English. The motive of using this strategy was to make the students understand the teacher's intentions easily and this could prevent misunderstanding of the teacher's intentions especially for students who had low English proficiency. This result was in line with the notion of code switching proposed by Dornyei and Scott in [6]. They mentioned code switching means the speakers use L1/L3 words with L1/L3 pronunciation in L2 speech; this may involve stretches of discourse ranging from single words to whole chunks even complete turns. [8] supported code switching strategy was believed as effective strategy in English language classroom when dealing with low English proficient learners.

Second direct strategy used by the teacher was self-repair. She repaired her previous utterance as she realized she used wrong words when she read stories and explained lesson to students. She directly repaired the wrong words in order to avoid misunderstanding among teacher's intention and students' comprehension. This result was supported by Dornyei and Scott in [6]. They mentioned self-repair means the speakers make self-initiated correction on their own speech. The teacher in this study used this strategy to motivate students to use appropriate words and this could keep the communication running well.

Other-repair strategy was another direct strategy used by the teacher when the students told her about something. Usually, she repaired the structure of the sentence especially when the students told about past events. She used this strategy in order to make the students know the appropriate words that they had to use in telling past events. Dornyei and Scott in [6] mentioned other-repair means the speakers correct something in interlocutor's speech. Thus, related to this study, the other-repair strategy used by the teacher to correct words in students' speech to make the students use correct words later.

The last direct strategy used by English native speaker teacher was self rephrasing. She rephrased her previous words to simpler one as not all of the students understand the teacher's intention. By using self-rephrasing, the teacher could use simple word to explain a term to the students. Dornyei and Scott in [6] stated self-rephrasing means the speaker repeated a term but it is not quite as it is. The speaker might add something or use paraphrase. The teacher in this study paraphrased her previous utterance to make the students understand her intention easily.

Moreover, in indirect strategy, there were three strategies used by English native speaker teacher. First, she applied use of fillers such as OK, actually, you know, and well when she started talking to the students because she wanted her speaking sound friendlier. Moreover, she needed time to think what she could share to students. Dornyei and Scott in [6] mentioned use of fillers means speakers use gambits to fill pause, to stall and to gain time in order to keep communication channel open. This was in line with the result of this study; the teacher used this strategy to gain time to think what to say next [9] supported use of fillers was intended to mark of hesitation, time creating device, editing term and hold control of conversation while the teachers think what to share to the students.

Self-repetition was another indirect strategy used by the English native speaker teacher in order to make sure all students listen and to tell information to the students clearly. When the students understood the intentions, the students could do what the teacher mentioned during the learning time. According to Dornyei and Scott in [6], self-repetition means the speakers repeat words immediately after they were said. This study showed the teacher used this strategy immediately after first utterance was mentioned to explain lesson and give instruction to the students.

Other-repetition was the last indirect strategy used by the English native speaker teacher. She repeated students' utterance when she asked questions to the students. This was done to make sure all students listen and know the appropriate answer in the 
discussion. Other repetition, according to Dornyei and Scott in [6] means the speaker repeated something the interlocutor said to gain time. In this study, the teacher repeated students' appropriate answer or good opinion to make other students could learn from their friends. By repeating students' words, it could give opportunity for the students who had limited English vocabulary to learn more from their friends and teacher. This is in line with a study done by [10]. They showed the teacher' reason used self-repetition is to increase the amount of input especially when the teacher gives information or correction.

In interactional strategies, the teacher used six strategies during the English sessions. First, asking for repetition strategy was used when the teacher could not hear and get the students' intentions. This was in line with Dornyei and Scott in [6]. Asking for repetition means the speaker asked the interlocutor to repeat as the speakers do not hear and understand properly. In this study, the teacher used this strategy to have clear information from the students. When she asked the students to repeat what they mentioned previously, she also wanted other students listen to the opinion. Thus, they could learn from the students who share opinion during discussion.

Second interactional strategy used by the English native speaker teacher was asking for clarification in order to make students talk more and to gain more information from the students. When the teacher asked the students to clarify their intention, the teacher, indirectly, trained the students to be confident in telling their intention. According to Dornyei and Scott in [5], asking for clarification was same with the result of this study. The speakers request explanation of unfamiliar meaning. Teacher asked the students to clarify their intention to make information become clearer. Moreover, Chin; Nassaji and Well in [11] supported the teacher used asking for clarification of the students' previous contribution to enhance students' existing knowledge.

Asking for confirmation was another interactional strategy used by English native speaker teacher to have clear information and to make sure what she heard was same with the students' intention. This was in line with asking for confirmation mentioned by Dornyei and Scott in [6]. The speakers request confirmation that they heard. In this study, the teacher asked for confirmation of students' opinion during stories and discussions to have clear understanding of the message shared by the students.

The fourth interactional strategy used by the teacher was comprehension check to ensure students' understanding toward the stories and topic in the class. This result was in line with Dornyei and Scott in [6]. They mentioned comprehension check means the speaker ask questions to check that the interlocutor can follow what the speakers want. This strategy was to make students engaged in classroom interaction. Teacher could make sure students were following the lesson and kept focusing on the discussion.

Guessing was another interactional strategy used by the teacher. She used this strategy to help and support the students in telling their intentions in English. Some students had limited vocabularies in English. Dornyei and Scott in [6] mentioned guessing strategy is similar to a confirmation request but latter implies a greater degree of certainty regarding the key word. Relating to this study, the teacher used this strategy as students did not know how to say the words and they only gave code. The teacher tried to guess; thus, students could know how to tell their intentions and this could develop their English vocabularies.

Last interactional strategy used by English native speaker teacher was response. The teacher applied this strategy usually after the students gave opinion during discussion. According to Dornyei and Scott in [6], response strategy consisted of response repeat, repair, rephrase, expand, confirm and reject. However, in this study, the teacher responded only by confirming appropriate answers or rejecting students' inappropriate answers. This was done to acknowledge students' contribution in the class and prevent misunderstanding as students would know whether their answers were appropriate or not. 


\section{Conclusion}

The use of communication strategies is necessary in teaching and learning process. In this study, communication strategies used by English native speaker teacher at Dyatmika Kindergarten showed the teacher attempted to make students understand the teacher's intentions and solve the problem when the teacher communicated with the students. Classification of communication strategies proposed by Dornyei and Scott in [6] was used in analysing types of communication strategies used by the English native speaker teacher. The result showed there were thirteen communication strategies used by the teacher during the carpet time in English sessions. This result could be used as reference to inspire teachers who teach inside or outside Dyatmika Kindergarten in teaching bilingual students.

Greatest gratitude goes to all lecturers of English Education of Postgraduate Program at Ganesha University of Education, Bali, Indonesia especially the principal supervisors, Prof. Dr. I Ketut Seken M.A and Prof. Dr. I Nyoman Adi Jaya Putra, M.A for their invaluable guidance, correction and motivation during this study.

\section{References}

1. M.E. Gredler. Learning and Instruction Theory into Practice (Sixth Edition). New Jersey: Pearson Education, Inc. (2009)

2. H.D. Brown. Principles of Language Learning and Teaching (Fifth Edition). New York: Pearson Education. (2007)

3. A. Maleki. Techniques to Teach Communication Strategies. JLTR 1 640-646. (2010)

4. I.G.A.I.T. Juliari. The Profile of Communication Strategy used by Junior High School English Teachers in Teaching and Learning Process in SMPN 2 Sukawati. EPPUPG 2 (2014)

5. K.A. Wedananta. Communication Strategies Used by Mathematics And Science Teachers to Communicate in English in Morning Sharing in SMP Nasional Plus Jembatan Budaya: A Sociolinguistic Analysis. EPPUPG 3 (2014).

6. Z. Dornyei, M.L. Scott. Communication Strategies in a Second Language: Definition and Taxonomies. LL, 47 173-210 (1997)

7. M.B Miles, A.M. Huberman. Qualitative Data Analysis (Second Edition). California: Sage Publication, Inc (1994)

8. B. H. Ahmad, K. Jussoff. Teachers' Code Switching in Classroom Instruction for Low English Proficient Learners. ELTJ 2 49-55 (2009)

9. V.A. Pamolango. Types and Functions of Fillers used by the Female Teacher and Lecturer in Surabaya. P 15 11-15 (2015)

10. M.D.M. Viano, P.G. Conejos. Communicative Functions of Repetition in Classroom Interaction. RESLA 11 129-141 (1996)

11. M.Y. Nothash, M.A. Karafkan. Teacher-employed Communication Strategies: Investigating Function Type Occurrence in Iranian EFL Context. IJALEL 4 73-80 (2015) 